\title{
An Unrecognized Fundamental Relationship between Neurotransmitters: Glutamate Protects against Catecholamine Oxidation
}

\author{
Wenping Wang ${ }^{1,+}$, Ximing $W u^{1, \dagger}$, Chung S. Yang ${ }^{1,2} \mathbb{D}$ and Jinsong Zhang ${ }^{1,3, * \mathbb{D}}$ \\ 1 State Key Laboratory of Tea Plant Biology and Utilization, School of Tea \& Food Science, \\ Anhui Agricultural University, Hefei 230036, China; wpw@ahau.edu.cn (W.W.); WXM@ahau.edu.cn (X.W.); \\ csyang@pharmacy.rutgers.edu (C.S.Y.) \\ 2 Department of Chemical Biology, Ernest Mario School of Pharmacy, Rutgers, \\ The State University of New Jersey, Piscataway, NJ 08854, USA \\ 3 International Joint Research Laboratory of Tea Chemistry and Health Effects, Anhui Agricultural University, \\ Hefei 230036, China \\ * Correspondence: zjs@ahau.edu.cn; Tel.: +86-551-6578-6765 \\ + These authors contributed equally to this work.
}

check for updates

Citation: Wang, W.; Wu, X.; Yang, C.S.; Zhang, J. An Unrecognized Fundamental Relationship between Neurotransmitters: Glutamate Protects against Catecholamine Oxidation. Antioxidants 2021, 10, 1564 https: / / doi.org/10.3390/ antiox10101564

Academic Editors: Andrii Domanskyi and Rosanna Parlato

Received: 30 July 2021

Accepted: 29 September 2021

Published: 30 September 2021

Publisher's Note: MDPI stays neutral with regard to jurisdictional claims in published maps and institutional affiliations.

Copyright: (c) 2021 by the authors. Licensee MDPI, Basel, Switzerland. This article is an open access article distributed under the terms and conditions of the Creative Commons Attribution (CC BY) license (https:/ / creativecommons.org/licenses/by/ $4.0 /)$.

\begin{abstract}
Neurotransmitter catecholamines (dopamine, epinephrine, and norepinephrine) are liable to undergo oxidation, which copper is deeply involved in. Catecholamine oxidation-derived neurotoxicity is recognized as a pivotal pathological mechanism in neurodegenerative diseases. Glutamate, as an excitatory neurotransmitter, is enriched in the brain at extremely high concentrations. However, the chemical biology relationship of these two classes of neurotransmitters remains largely unknown. In the present study, we assessed the influences of glutamate on the autoxidation of catecholamines, the copper- and copper-containing ceruloplasmin-mediated oxidation of catecholamines, the catecholamine-induced formation of quinoprotein, catecholamine/copper-induced hydroxyl radicals, and DNA damage in vitro. The results demonstrate that glutamate, at a physiologically achievable molar ratio of glutamate/catecholamines, has a pronounced inhibitory effect on catecholamine oxidation, catecholamine oxidation-evoked hydroxyl radicals, quinoprotein, and DNA damage. The protective mechanism of glutamate against catecholamine oxidation could be attributed to its restriction of the redox activity of copper via chelation. This previously unrecognized link between glutamate, catecholamines, and copper suggests that neurodegenerative disorders may occur and develop once the built-in equilibrium is disrupted and brings new insight into developing more effective prevention and treatment strategies for neurodegenerative diseases.
\end{abstract}

Keywords: catecholamines; dopamine; glutamate; neurotransmitters; oxidation

\section{Introduction}

Catecholamines, such as dopamine and norepinephrine, take part in regulating a variety of mental processes, including cognitive ability, attention, memory, mood, and reward [1-5]. Catecholamines have adjacent hydroxyl groups on their benzene rings [6], thus making them susceptible to autoxidation, and produce hydrogen peroxide [7-9], semiquinone anion radicals [8,10], and quinones [11,12]. Quinones further initiate intramolecular cyclization to form the end products of neuromelanin polymers [13-17]. All these intermediates and end products may be toxic to neuron cells, and thus the autoxidation of catecholamines is considered to be an important mechanism of neuron cell loss in Parkinson's disease [18-21]. Moreover, the disorder of copper homeostasis is involved in neurological diseases, such as Parkinson's disease [22,23]. Redox-active copper can facilitate the oxidation of catecholamines via the formation of hydroxyl radicals [24,25]. It is known that DNA is an especially sensitive site within the cell for copper-mediated damage because copper ions have a high affinity for DNA, forming a DNA-Cu complex [26,27]. 
Catecholamines and DNA-localized copper can cause DNA damage via the site-specific attack of hydroxyl radicals on DNA $[25,26]$.

Glutamate, as a neurotransmitter, plays an important role in learning, memory, neuronal plasticity, and brain development [28-32]. The excessive stimulation of glutamate receptors causes the excitatory toxicity of neuron cells [33,34]; thus, neurons are endowed with high-affinity glutamate transporters to enrich glutamate [35]. Consequently, extracellular glutamate concentrations, or interstitial fluid glutamate concentrations, are maintained in levels as low as $0.5-5 \mu \mathrm{M}$ [36], and intracellular concentrations of glutamate reach as high as $6-12 \mathrm{mM}$ [35]. In contrast, the intracellular concentrations of dopamine, the major catecholamine neurotransmitter in dopaminergic neurons, are only at the level of 0.05-0.1 mM [37-39]. The present study investigated whether glutamate has an impact on catecholamine oxidation in vitro. We found that glutamate was able to prevent the autoxidation of catecholamines and autoxidation-associated quinoprotein formation, the copper-mediated oxidation of catecholamines, catecholamine/copper-triggered DNA damage, and quinoprotein formation.

\section{Materials and Methods}

\subsection{Chemicals and Drugs}

Dopamine (hydrochloride) (CAS. No: 28094-15-7) was purchased from Solarbio Science \& Technology Co., Ltd. (Beijing, China). Norepinephrine (CAS. No: 51-41-2), epinephrine (CAS. No: 51-43-4), and glutamate (CAS. No: 6893-26-1) were obtained from Macklin Biochemical Co., Ltd. (Shanghai, China). 3, 4-dihydroxyphenylacetaldehyde (DOPAL) (CAS. No: 5707-55-1) was a product of Santa Cruz Biotech (Dallas, TX, USA). Ceruloplasmin (CAS. No: 9031-37-2), monoamine oxidase (MAO) (M7316), 2', $7^{\prime}$-dichlorofluorescin diacetate (DCFH-DA) (CAS. No: 4091-99-0), 3-hydroxycinnamic acid (3-CCA) (CAS. No: 531-81-7), dithiothreitol (CAS. No: 3483-12-3), glyceraldehyde-3-phosphate dehydrogenase (GAPDH) (CAS. No: 9001-50-7), and nitroblue tetrazolium (NBT) (CAS. No: 298-83-9) were purchased from Sigma (St. Louis, MO, USA). The polyvinylidene difluoride (PVDF) membrane was a product of Bio-Rad Laboratories, Inc. (Hercules, CA, USA). Plasmid pBR322 DNA (\#N3033L) was obtained from New England Biolabs (Beijing, China). Other chemicals used were of the highest grade available.

\subsection{Dopamine Oxidation Assessment}

Dopamine was incubated in a $0.15 \mathrm{M}, \mathrm{pH} 7.4$ phosphate buffer solution (PBS) at $37^{\circ} \mathrm{C}$. With the increase in oxidation time, the dopamine solution gradually oxidized to yellow. According to the results of spectral scanning, an absorption value of $410 \mathrm{~nm}$ was selected to characterize the oxidation degree of the dopamine. Kinetic alterations were recorded using a plate reader (Molecular Devices SpectraMax M2e, Sunnyvale, CA, USA).

\subsection{Detection of Reactive Oxygen Species}

To detect reactive oxygen species, dopamine was incubated in PBS (0.15 M, pH 7.4) containing $50 \mu \mathrm{M}$ of DCFH-DA at $37^{\circ} \mathrm{C}$. Dynamic changes in fluorescence intensity were recorded using the aforementioned plate reader at an excitation wavelength of $488 \mathrm{~nm}$ and an emission wavelength of $525 \mathrm{~nm}$.

\subsection{Detection of Hydroxyl Radicals}

The chemicals were co-incubated with $3 \mathrm{mM}$ of 3-CCA as a fluorescent probe at $37^{\circ} \mathrm{C}$. The dynamic curve of the fluorescence intensity was recorded using the aforementioned plate reader. The excitation and emission wavelengths were $388 \mathrm{~nm}$ and $446 \mathrm{~nm}$, respectively.

\subsection{Detection of DNA Damage}

DNA cleavage was evaluated by agarose gel electrophoresis using pBR322 plasmid DNA. The DNA and chemicals were mixed in $0.15 \mathrm{M}$ PBS ( $\mathrm{pH} 7.4$ ) at a final volume of 
$50 \mu \mathrm{L}$ and incubated at $37^{\circ} \mathrm{C}$. The samples were loaded by $6 \times$ DNA loading buffer in $1 \%$ agarose gel containing $40 \mathrm{mM}$ of Tris-acetate and $1 \mathrm{mM}$ of EDTA (pH 8.0) as well as Super/Gel Red (Tiangen Biotech, Beijing, China). In $1 \times$ TAE gel buffer, electrophoresis was carried out on a horizontal plate gel apparatus under $90 \mathrm{~V}$ conditions for $1 \mathrm{~h}$.

\subsection{NBT/Glycinate Redox-Cycling Staining of Quinoprotein}

The chemicals and GAPDH were mixed in 0.15 M PBS (pH 7.4) at $37{ }^{\circ} \mathrm{C}$ and the reaction was terminated by adding dithiothreitol. Then, $10 \%$ SDS polyacrylamide gels were used for second-dimension electrophoresis. The proteins on the gel were transferred to a methanol-soaked PVDF membrane in an electrophoresis transfer solution. The quinoproteins were stained by redox-cycling staining [40,41]. Briefly, the membrane was incubated with $0.24 \mathrm{mM}$ NBT in $2 \mathrm{M}$ potassium glycinate ( $\mathrm{pH}$ 10.0) in the dark to form purple bands, then the stained membrane was rinsed with distilled water.

\subsection{Dopamine Retention Detected by High Performance Liquid Chromatography (HPLC)}

Dopamine was quantitatively detected by HPLC (Waters Instruments, Inc., Rochester, $\mathrm{MN})$. Chromatographic separation was performed on a Gemini 5 u C18 110 A column $(250 \times 4.60 \mathrm{~mm}$, Phenomenex Inc., Torrance, CA, USA). The separation conditions were as follows: the column temperature was maintained at $30^{\circ} \mathrm{C}$, the flow rate was $1 \mathrm{~mL} / \mathrm{min}$, the single injection volume was $10 \mu \mathrm{L}$, and the mobile phases were (A) $0.15 \%$ acetic acid-water (ultra-pure water plus $0.15 \%$ acetic acid) and (B) acetonitrile. A gradient elution separation method was set, the total detection time was $40 \mathrm{~min}$, and phase A was taken as an example: (1) Initial mobile phase proportion A: 85\%, keep running for $10 \mathrm{~min}$; (2) switch to another gradient elution A: 77\%, run for $15 \mathrm{~min}$; (3) reduce to A: 71\% within $1 \mathrm{~min}$; (4) convert A: $0 \%$ at the 26th min and maintain for $4 \mathrm{~min}$; (5) return to initial state A: $85 \%$ within 2 min and maintain for $8 \mathrm{~min}$; (6) switch to A: $80 \%$ at $40 \mathrm{~min}$ and maintain the balance system for the next injection. The amount of dopamine in the eluent was measured by the absorbance with wavelengths of $278 \mathrm{~nm}$.

\subsection{Determination of Ceruloplasmin Ferrous Oxidase Activity}

Ceruloplasmin ferrous oxidase activity was determined using a kit purchased from Jiancheng Bioengineering Institute (Nanjing, China).

\section{Results and Discussion}

\subsection{Autoxidation of Dopamine and the Protective Role of Glutamate}

Under alkaline and aerobic conditions, dopamine can undergo autoxidation to form quinones and produce hydrogen peroxide [9,42]. The quinones further polymerize to form macromolecular neuromelanin polymers, which increase the pigmentation of neurons in the substantia nigra [43]. The pigmented dopaminergic neurons in the substantia nigra are preferentially lost in Parkinson's disease [13]. In the present study, $10 \mathrm{mM}$ of dopamine was used to observe time-dependent color development due to dopamine oxidation under physiological conditions (a pH 7.4, 0.15 M PBS). Compared to dopamine alone, the addition of $-200 \mathrm{mM}$ of glutamate effectively inhibited dopamine oxidation, while that of $-500 \mathrm{mM}$ of glutamate almost completely inhibited the oxidation, as evaluated by the color development at OD410nm (Figure 1A). Since dopamine autoxidation leads to the formation of reactive oxygen species (ROS), $50 \mu \mathrm{M}$ of DCFH-DA as a fluorescent probe was used to detect the ROS produced by $10 \mathrm{mM}$ of dopamine. The production of ROS was significantly inhibited by $-200 \mathrm{mM}$ of glutamate, while $500 \mathrm{mM}$ of glutamate nearly entirely inhibited ROS production (Figure 1B). During the nonenzymatic autoxidation process of dopamine, intermediate quinones can covalently react with cysteine sulfhydryl groups in proteins or enzymes, leading to the formation of quinoproteins $[8,44,45]$. Quinoprotein adduct formation may play a role in the age-dependent selective vulnerability of dopaminergic neurons in Parkinson's disease [46]. To detect the production of dopaminequinoproteins, dopamine and GAPDH (with a free thiol group of a cysteine residue at 
position 151) were co-incubated at $37^{\circ} \mathrm{C}$ for $1 \mathrm{~h}$ in vitro. As shown in Figure 1C, in the absence of dopamine, quinoproteins were not observed (lane 2). After a $1 \mathrm{~h}$ co-incubation of GAPDH and dopamine $(5 \mathrm{mM})$, dopamine-quinoproteins could be clearly visualized (lane 3). The addition of glutamate $(500 \mathrm{mM}$, lane 1$)$ sufficiently inhibited quinoprotein formation. These results together suggest that glutamate has an inhibitory effect on the autoxidation of dopamine. However, the specific mechanism involved is not clear. We speculated that this may involve the nature of autoxidation. In fact, the spin limitation of dioxygen is a dynamic barrier to the oxidation of biomolecules such as dopamine [47]. The direct reaction between the two requires a large amount of activation energy; thus, the oxidation rate of biomolecules is very slow and the real autoxidation of biomolecules is a negligible process [47]. However, many transition metals with various spin states can overcome the spin limitation of dioxygen and thus increase the oxidation rate of biomolecules. The commonly described autoxidation of biomolecules such as catecholamines is actually promoted by transition metals [47]. David et al. proposed that the oxidation of dopamine in the absence of added copper may be significantly influenced by the presence of metal impurities [48]. In deionized water that was further purified by chromatography over Chelex 100 resin prior to use, epinephrine does not autoxidize. However, epinephrine was oxidized rapidly in deionized water, but this oxidation could be prevented by desferal (a potent metal chelating agent) [49]. The autoxidation of (-)-epigallocatechin-3-gallate, a welldocumented redox-active catechin mainly found in green tea, can be largely prevented by EDTA, indicating that trace amounts of transition metals are involved in the autoxidation process [50]. Many buffer systems, especially phosphate, can form complexes with transition metals. Thus, in many experimental systems, the presence of trace metals in the buffer is inevitable [47]. Put simply, there is no pure "autoxidation". The essence of biomolecule autoxidation is oxidation involving trace amounts of transition metals. It has been reported that glutamate can react with copper by forming complexes [51,52]. Indeed, as shown in Figure 1D, the characteristic blue color of glutamate-copper complexes is enhanced as a function of the increased glutamate concentrations. Preformed glutamate-copper complexes consistently show a compromised capacity to promote dopamine oxidation as compared with free copper (Figure 1E). We thus speculate that the inhibitory effect of glutamate on the autoxidation of dopamine could be attributed to glutamate's restriction on redox-active copper bound to dopamine or the buffer system. Since trace amounts of transition metals, which promote the autoxidation of biomolecules, form complexes with biomolecules and/or buffers, as much as $14 \mathrm{mM}$ of EDTA was required to effectively suppress the "autoxidation" of (-)-epigallocatechin-3-gallate [50]. The present study also consistently showed that higher molar ratios of glutamate/dopamine were needed to fully inhibit the autoxidation of dopamine. In the case of the free copper-promoted oxidation of dopamine, which has been implicated in dopamine-associated toxicity [11,53], we estimated that glutamate would be highly effective in preventing dopamine oxidation-i.e., to achieve an effective protective effect, the molar ratios of glutamate/dopamine are significantly lowered compared to the case of dopamine "autoxidation". Next, we examined this possibility.

\subsection{Glutamate Protects against Copper-Facilitated Dopamine Oxidation}

It is surprising that substantial concentrations of both dopamine and copper $(0.4 \mathrm{mM})$ coexist in the substantia nigra, although the precise free copper concentration is not known $[48,54]$. Moreover, many studies have shown that copper levels are elevated in the cerebrospinal fluid (CSF) of patients with Parkinson's disease $[55,56]$. Copper can facilitate dopamine oxidation and meanwhile leads to the production of highly active hydroxyl radicals and, accordingly, DNA damage $[25,57]$. These processes may contribute to the observed loss of dopaminergic neurons in patients with Parkinson's disease [58]. Therefore, we further evaluated the influence of glutamate on copper-accelerated dopamine oxidation. As shown in Figure 2A, compared with $0.5 \mathrm{mM}$ of dopamine alone, the addition of $100 \mu \mathrm{M}$ of copper hugely promoted the oxidation of dopamine. Glutamate at a concen- 
tration of $5 \mathrm{mM}$ effectively suppressed copper-promoted dopamine oxidation (Figure 2A). Concerning hydroxyl radical production by copper and dopamine, we used a hydroxyl radical-specific probe, the 3-CCA, for the assessment. In a redox system of $0.5 \mathrm{mM}$ of dopamine and $50 \mu \mathrm{M}$ of copper, hydroxyl radical production was clearly sensed by the 3-CCA. In this redox system, the addition of glutamate at a concentration of only $2.5 \mathrm{mM}$ substantially inhibited hydroxyl radical production (Figure 2B). In addition, we used HPLC to detect dopamine retention. As shown in Figure 2C, the copper facilitated dopamine oxidation in a time-dependent manner. After 3-h incubation of copper and $0.5 \mathrm{mM}$ of dopamine, about $30 \%$ of the dopamine remained. At the same time, it was observed that the glutamate inhibited the copper-mediated dopamine oxidation in a dose-dependent manner. Specifically, the retention of dopamine could be effectively increased by as low as $1 \mathrm{mM}$ of glutamate, and near-complete retention of dopamine could be achieved by $5 \mathrm{mM}$ of glutamate (Figure 2C). We further characterized the influence of glutamate on dopamine-initiated quinoprotein formation (Figure 2D). Following a 20-min incubation of $0.2 \mathrm{mM}$ of dopamine and GADPH, quinoproteins were hardly detected (lane 1). Under the circumstances, copper markedly promoted quinoprotein formation (lane 2). Nonetheless, glutamate was able to dose-dependently inhibit copper-initiated quinoprotein formation. A low concentration of glutamate $(1 \mathrm{mM})$ could be significantly effective (lane 3 ), while $10 \mathrm{mM}$ of glutamate almost completely inhibited copper-initiated quinoprotein formation (lane 4). Altogether, these four lines of evidence clearly demonstrate that glutamate is highly effective in inhibiting copper-facilitated dopamine oxidation.
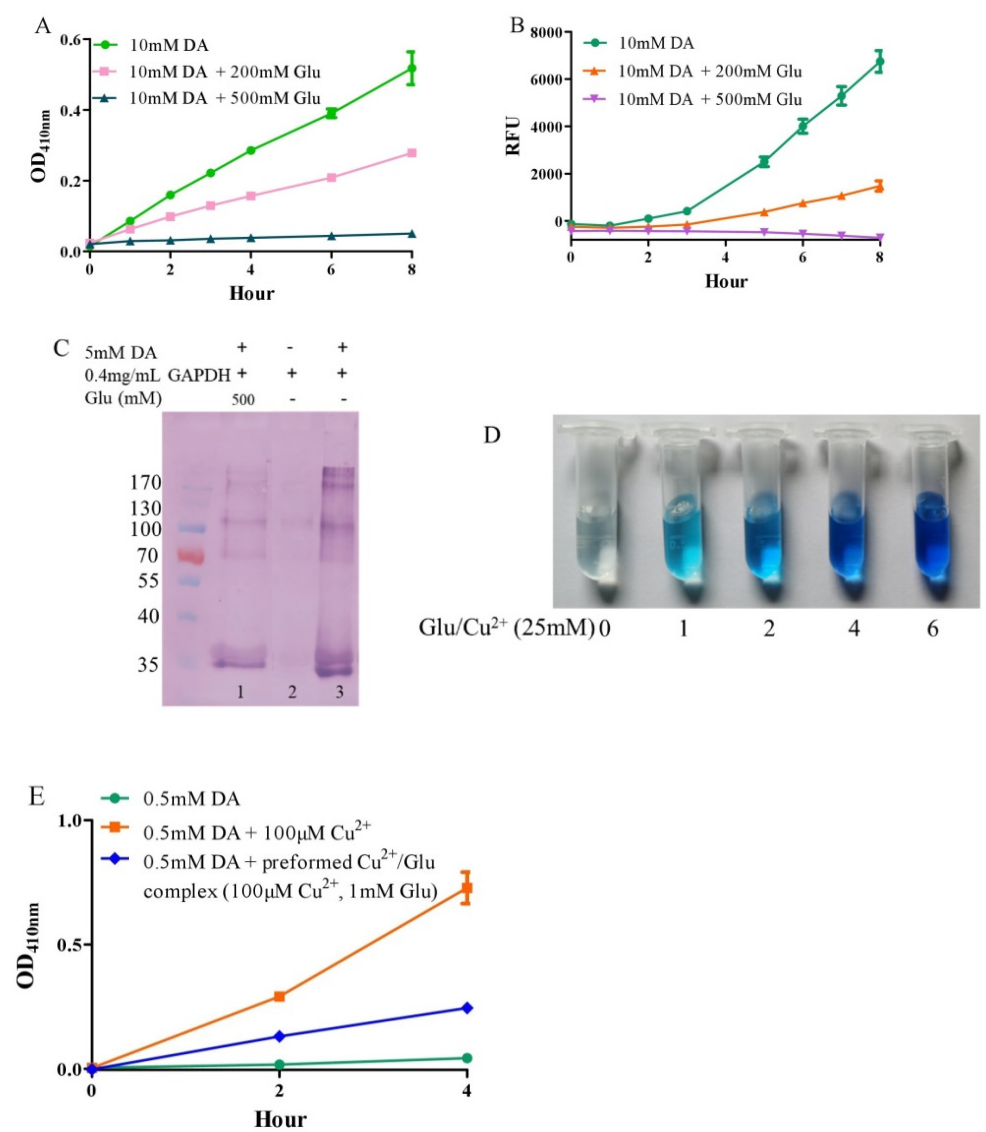

Figure 1. Autoxidation of dopamine and the protective role of glutamate. (A) Dopamine autoxidationmeasured by $\mathrm{OD}_{410 \mathrm{~nm}}$. (B) Dopamine-caused ROS production detected by DCFH-DA. (C) Dopamine-caused quinoprotein in GAPDH. (D) Glutamate-copper complexes. (E) Influence of free copper and preformed copper-glutamate complex on dopamine oxidation. Chemicals were mixed in 0.15 M PBS ( $\mathrm{pH} 7.4$ ) and incubated at $37{ }^{\circ} \mathrm{C}$ for indicated time or $1 \mathrm{~h}$ for $\mathrm{C}$. Data are presented as mean \pm range $(n=2)$. Note: DA: Dopamine, Glu: Glutamate. 

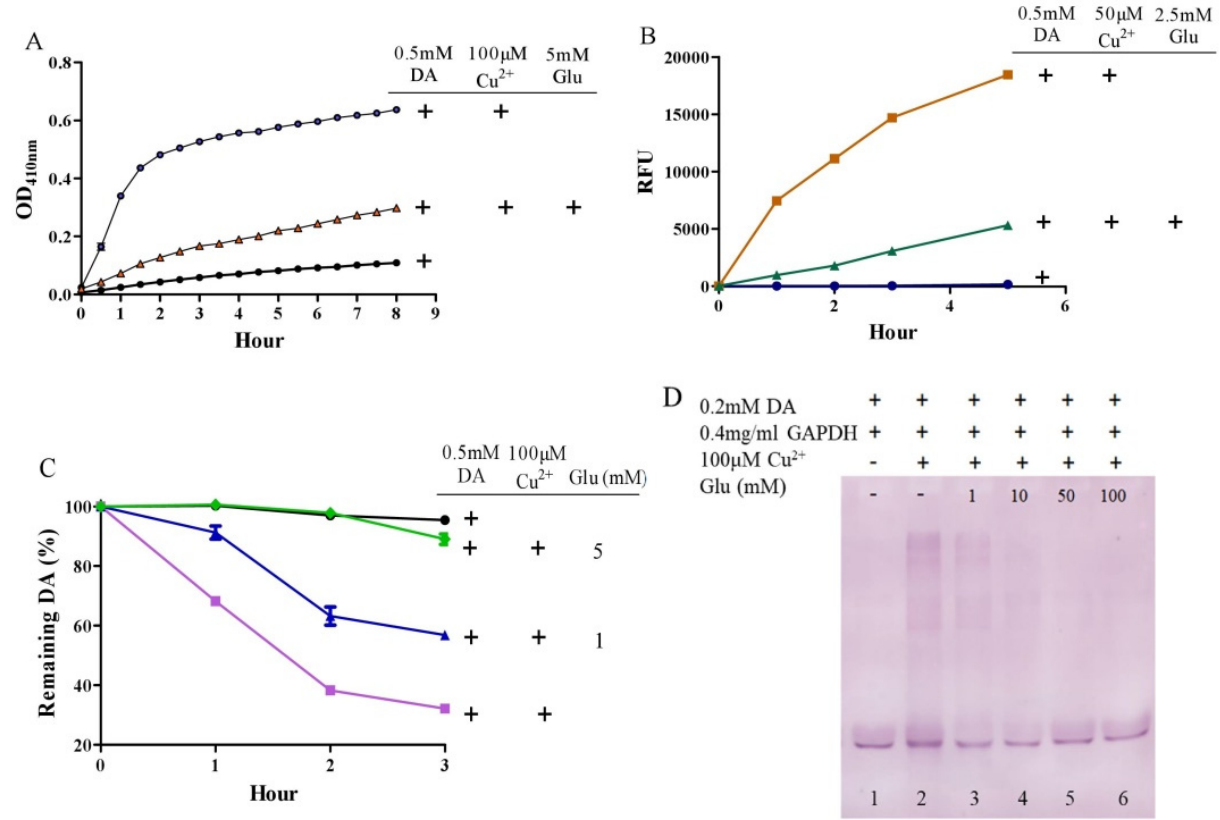

Figure 2. Glutamate protects against copper-induced dopamine oxidation. (A) Dopamine oxidation measured by $\mathrm{OD}_{410 \mathrm{~nm}}$. (B) Hydroxyl radicals detected by 3-CCA. (C) Dopamine levels detected by HPLC. (D) Dopamine-caused quinoprotein in GAPDH. Chemicals were mixed in 0.15 M PBS (pH 7.4) and incubated at $37^{\circ} \mathrm{C}$ for indicated time or $20 \mathrm{~min}$ for $\mathrm{D}$. Data are presented as mean \pm range $(n=2)$. Note: DA: Dopamine, Glu: Glutamate.

\subsection{Glutamate Protects against Ceruloplasmin-Facilitated Dopamine Oxidation and Dopamine Oxidation-Caused Modification of Ceruloplamin}

Ceruloplasmin, as expressed in human brain glial cells [59,60], is a ferrous oxidase. Ceruloplasmin plays an important role in iron homeostasis by oxidizing toxic ferrous iron so as to favor the strong binding of ferric iron to serum transferrin [61-63]. Ceruloplasmin with six copper atoms $[64,65]$ also catalyzes the oxidation of catecholamines $[24,49,66-68]$. Epinephrine oxidation rates enhanced by ceruloplasmin can be slowed down by a metal chelating agent [49], suggesting that copper bound to either epinephrine or ceruloplasmin is probably involved in this catalytic reaction. We thus inferred that glutamate would be able to restrict ceruloplasmin-facilitated dopamine oxidation by forming complexes with copper. To examine this possibility, we measured dopamine oxidation catalyzed by ceruloplasmin and investigated the potential impact of glutamate on dopamine oxidation catalyzed by ceruloplasmin using HPLC. Ceruloplasmin (equivalent to $5 \mu \mathrm{M}$ of copper) promoted the oxidation of $0.1 \mathrm{mM}$ of dopamine, while $10 \mathrm{mM}$ of glutamate inhibited the ceruloplasmin-catalyzed oxidation of dopamine (Figure 3A). Despite the fact that ceruloplasmin ferrous oxidase can be suppressed by a metal chelating agent such as EDTA [69], glutamate at levels that suppressed the dopamine oxidation activity of ceruloplasmin (Figure 3A) did not affect the activity of ceruloplasmin ferrous oxidase (Figure 3B). This is probably due to the different manner of copper dependence in the two types of activity. Importantly, we found that ceruloplasmin-triggered dopamine oxidation, in turn, caused the quinonization of ceruloplasmin with the formation of quinoproteins. As shown in Figure 3C, in the absence of dopamine, quinoproteins were unable to be detected from the ceruloplasmin (lane 1). In the presence of $1 \mathrm{mM}$ of dopamine, the quinonization of the ceruloplasmin was salient (lane 2). Nonetheless, 100-200 mM of glutamate was highly effective in protecting against the quinonization of the ceruloplasmin (lane 3, 4). Dopamine-caused quinonization of ceruloplasmin suggests that (1) oxidized products of dopamine generated from ceruloplasmin include highly active and thus harmful quinones, and (2) the reciprocal interaction of dopamine and ceruloplasmin may impair the ferrous oxidase activity of ceruloplasmin due to quinonization, thus increasing the accumulation of 
ferrous ion, leading to hydroxyl radical-associated oxidative stress. Decreased ceruloplasmin levels are associated with an earlier onset of Parkinson's disease [70-72]. Many studies have observed low ceruloplasmin ferrous oxidase activity in the substantia nigra and CSF of Parkinson's disease patients [73-75]. However, the relevant molecular mechanism remains elusive. The interplay of dopamine and ceruloplasmin firstly identified herein may be responsible, at least in part, for the loss of the ferrous oxidase activity of ceruloplasmin. Fortunately, the reciprocal interaction of dopamine and ceruloplasmin, with a loss at both sides, can be effectively halted by glutamate.
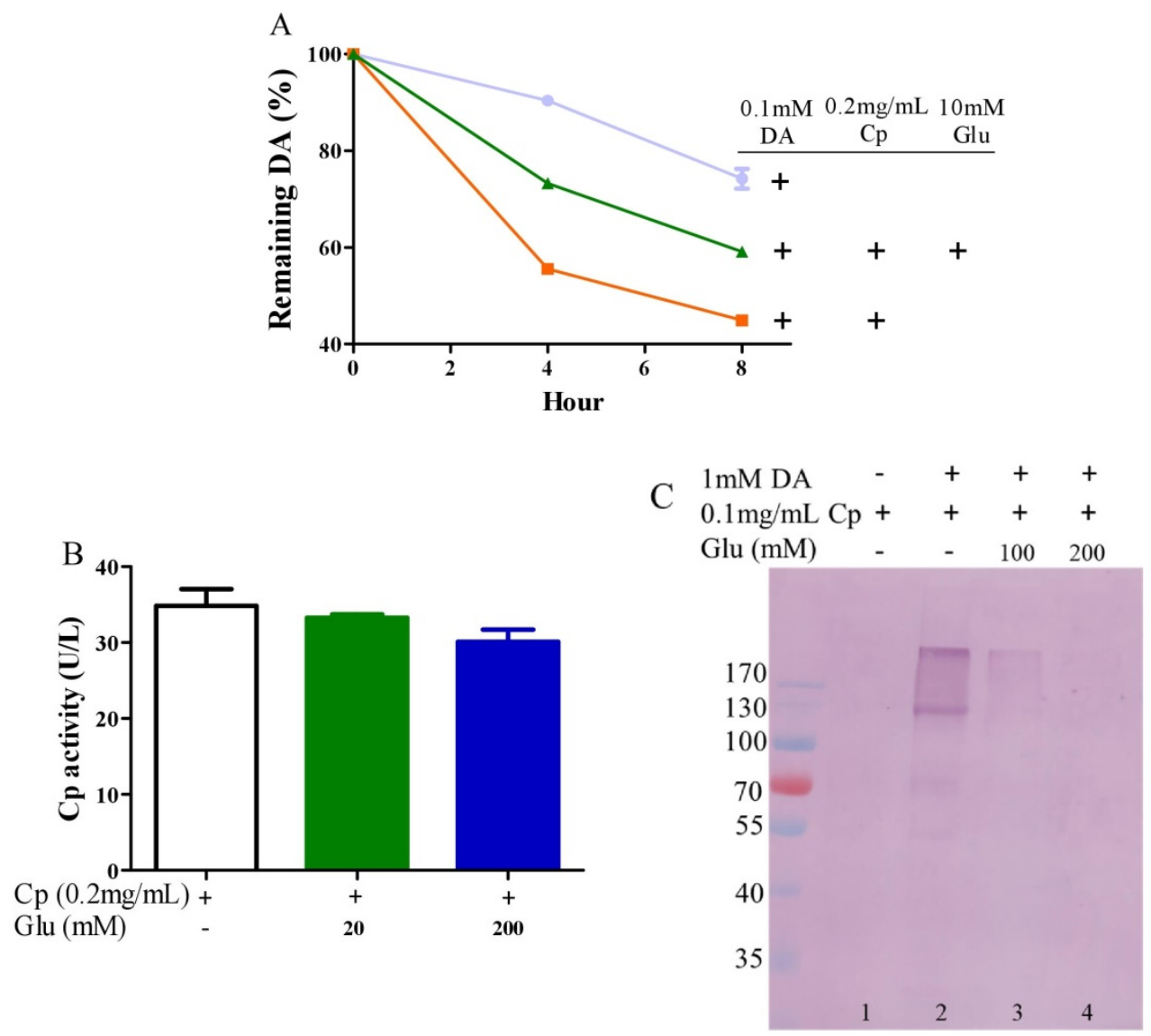

Figure 3. Glutamate protects against ceruloplasmin-promoted dopamine oxidation. (A) Dopamine levels detected by HPLC. (B) Ferrous oxidase activity of ceruloplasmin. (C) Dopamine-caused quinoprotein in ceruloplasmin. All reactions were conducted in $0.15 \mathrm{M}$ PBS (pH 7.4) and incubated at $37^{\circ} \mathrm{C}$ for indicated time or $1 \mathrm{~h}$ for $(\mathbf{C})$. Data are presented as mean \pm range $(n=2)$. Note: DA: Dopamine, Glu: Glutamate, Cp: Ceruloplasmin.

\subsection{Glutamate Inhibits Copper/Catecholamine-Induced DNA Damage}

Since about $20 \%$ of copper is stored in the nucleus and copper is an essential component of chromatin [76], DNA is the primary target of copper/catecholamine-derived hydroxyl radicals [55]. As shown in Figure 4A, where lane 1 was the DNA prototype, $100 \mu \mathrm{M}$ of dopamine perhaps had a weak damage effect (lane 2), and copper alone did not damage the DNA (lane 3). Dopamine-induced DNA damage was aggravated by copper in a dose-dependent manner (lane 6,4). Specifically, while $10 \mu \mathrm{M}$ of copper only initiated secondary DNA damage (lane 6), DNA degradation was almost completed by $25 \mu \mathrm{M}$ of copper (lane 4). Under these conditions, -2.5 and $10 \mathrm{mM}$ of glutamate, respectively, effectively inhibited the DNA damage (lane 7,5). Similarly, when the dopamine was replaced with the same dose of norepinephrine or epinephrine $(100 \mu \mathrm{M})$, copper was again found to promote DNA damage (Figure 4B, lane 2, and Figure 4C, lane 3). Again, glutamate dose-dependently inhibited the DNA damage (Figure 4B,C) and $10 \mathrm{mM}$ of glutamate nearly completely inhibited the DNA damage (Figure 4B, lane 4, and Figure 4C, lane 6). The pro- 
tective role of glutamate on dopamine/copper-triggered DNA damage could be attributed to the inhibitory effect of glutamate on copper-promoted dopamine oxidation, as demonstrated above. We thus inferred that the protective role of glutamate on norepinephrine or epinephrine/copper-triggered DNA damage is also associated with the inhibitory effect of glutamate on copper-promoted norepinephrine or epinephrine oxidation. This was validated by our next experiment. Copper at a level of $100 \mu \mathrm{M}$ greatly promoted the oxidation of $1 \mathrm{mM}$ of norepinephrine or epinephrine, as assessed by OD410nm (Figure 5A,B); however, as little as $10 \mathrm{mM}$ of glutamate substantially suppressed the copper-mediated oxidation of the catecholamine (Figure 5A,B). Since the "autoxidation" of catecholamines should be iterated as the "trace transition metal-mediated oxidation" of catecholamines, and glutamate can restrain the "autoxidation" of dopamine by depriving the redox activity of copper, we thus hypothesized that glutamate ought to prevent norepinephrine or epinephrine from undergoing so-called autoxidation. Indeed, the oxidation of both norepinephrine (10 $\mathrm{mM})$ (Figure 5C) and epinephrine (5 $\mathrm{mM}$ ) (Figure 5D), as assessed by OD410nm, increased as a function of time; however, this was nearly completely inhibited by $500 \mathrm{mM}$ and $850 \mathrm{mM}$ of glutamate, respectively, according to the results shown in Figure 5C,D.

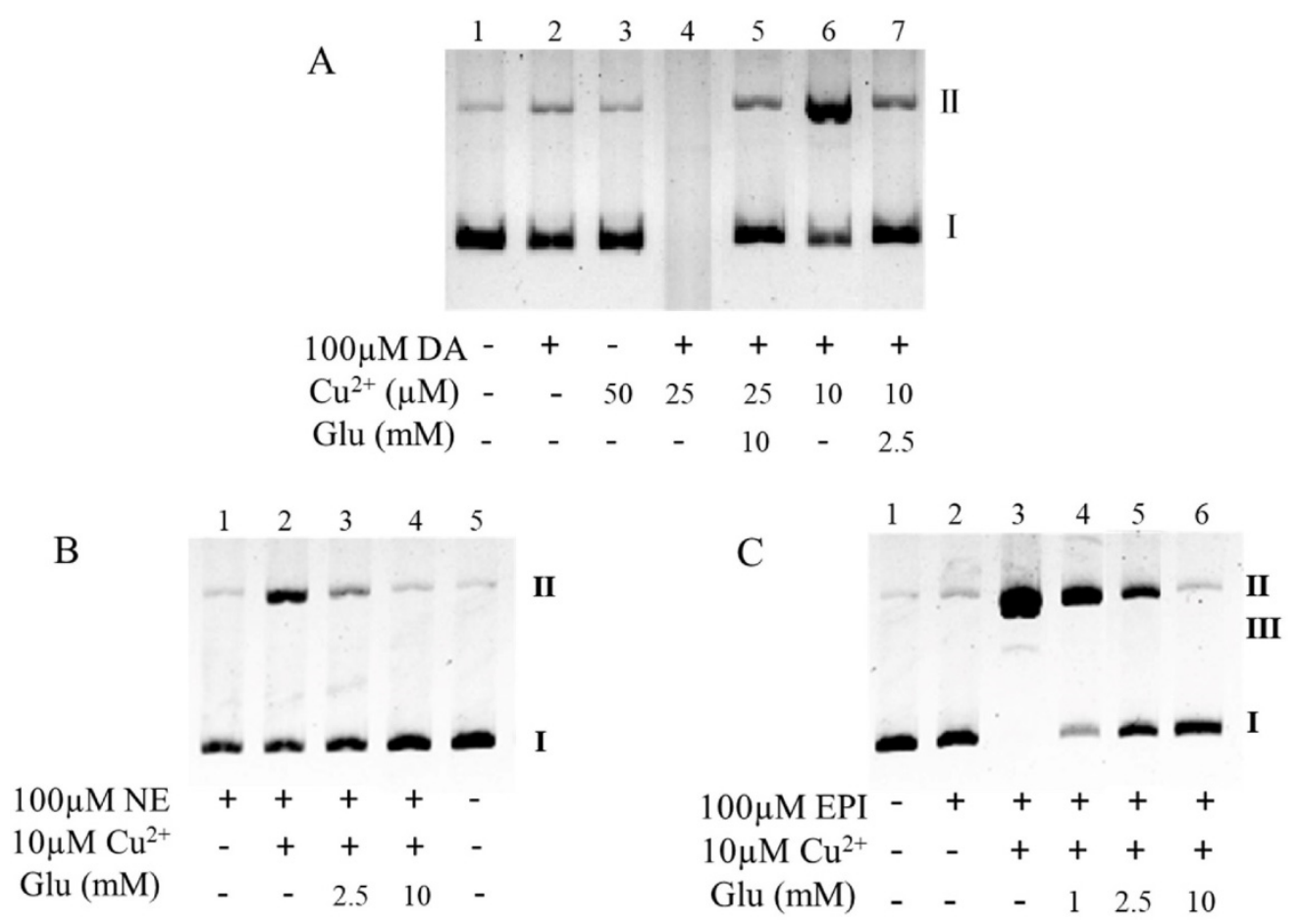

Figure 4. Glutamate protects against copper/catecholamine-induced DNA damage. (A) Dopamine. (B) Norepinephrine. (C) Epinephrine. Chemicals were mixed in 0.15 M PBS (pH 7.4) and incubated at $37^{\circ} \mathrm{C}$ for $1 \mathrm{~h}$. All reaction mixtures contained $10 \mu \mathrm{g} / \mathrm{mL}$ plasmid DNA. DNA structures: I, closed circular double-stranded supercoiled DNA; II, relaxed open circle DNA; and III, linear DNA. Note: DA: Dopamine, Glu: Glutamate, NE: Norepinephrine, EPI: Epinephrine. 

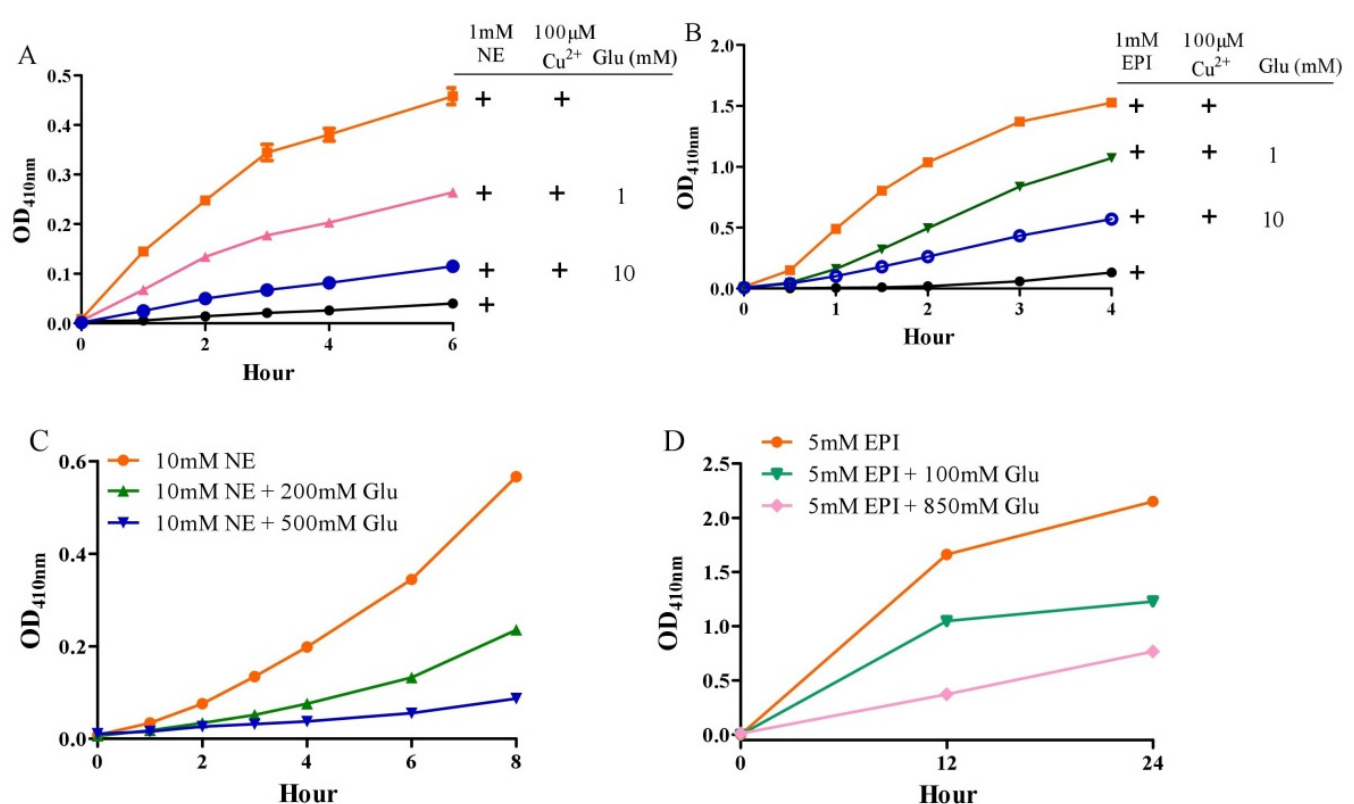

Figure 5. Influence of glutamate on norepinephrine or epinephrine oxidation. (A,B) Copper-promoted oxidation of norepinephrine and epinephrine, respectively, measured by $\mathrm{OD}_{410 \mathrm{~nm}} \cdot(\mathbf{C}, \mathbf{D})$ Norepinephrine and epinephrine autoxidation, respectively, measured by $\mathrm{OD}_{410 \mathrm{~nm}}$. Chemicals were mixed in $0.15 \mathrm{M}$ PBS (pH 7.4) and incubated at $37^{\circ} \mathrm{C}$ for indicated time. Data are presented as mean \pm range $(n=2)$. Note: Glu: Glutamate, NE: Norepinephrine, EPI: Epinephrine.

\subsection{Glutamate Protects against the Toxicity of 3, 4-Dihydroxy Phenylacetaldehyde}

MAO [77] catalyzes the oxidative deamination of dopamine to form DOPAL, which is then oxidized to DOPAL-quinone $[78,79]$. DOPAL, as the critical endogenous toxin causing dopaminergic neuron loss in Parkinson's disease, is 1000-fold more toxic than dopamine in vivo [80]. DOPAL-induced protein modifications were enhanced by copper [81]. Oxidatively damaged DNA, caused by catecholamine-related neurotoxins, contributes to neuronal death [26]. Although glutamate could not inhibit the MAO-mediated oxidation of dopamine (Figure 6A), it was able to powerfully inhibit DOPAL-induced quinoproteins (Figure 6B), DOPAL/copper-enhanced quinoprotein formation (Figure 6C), and DOPAL/copper-produced hydroxyl radicals (Figure 6D). The copper-mediated oxidative toxicity of DOPAL was also observed in DNA. As shown in Figure 6E, DOPAL and copper alone did not damage the DNA (lanes 1-3). However, when $100 \mu \mathrm{M}$ of DOPAL was added together with different concentrations of copper, copper-dependent DNA damage was observed: secondary damage with $10 \mu \mathrm{M}$ of copper (lane 6) and tertiary damage with 25 and $50 \mu \mathrm{M}$ of copper (lane 5 and 4 , respectively). A protective effect of $2.5 \mathrm{mM}$ of glutamate against copper-enhanced DOPAL damage to DNA was consistently observed at all the copper concentrations examined (lanes 10 vs. 6; lanes 9 vs. 5; lanes 8 vs. 4).

\subsection{Considerations of Molar Ratio of Glutamate to Dopamine}

Unlike neuromodulators such as dopamine and norepinephrine that show a marked regional distribution in the brain, glutamate is present at high concentrations in all cells via a high-affinity uptake system [35]. The human neuron-specific glutamate transporter (EAAT3) is densely expressed in dopaminergic neurons. The dense expression of EAAT3 in dopaminergic neurons not only detoxifies extracellular glutamate but also fulfills the high energy requirements of these cells, since glutamate participates in energy metabolism via glutamate dehydrogenase, which is also co-expressed in dopaminergic neurons [35]. It is known that the intracellular concentration of glutamate is approximately $10 \mathrm{mM}[35]$ and that the dopamine concentration in dopaminergic neurons is at the range of 0.05-0.1 mM [37-39]; therefore, the molar ratio of glutamate to dopamine could reach 200 in dopaminergic neurons. It should be noted that the dopamine concentrations used in the 
various in vitro experimental systems were not identical in the present study. The major reason why we did not use the same physiologically relevant concentration of dopamine in each test system, including dopamine oxidation, dopamine-caused quinoprotein formation, and dopamine/copper-triggered DNA damage, was the different sensitivities of the in vitro experimental approaches. Nonetheless, we always observed the protective effect of glutamate on the pro-oxidant actions of dopamine under a molar ratio of 200. It should be stated that these experiments were not carried out under physiological conditions and may not be related to processes taking place in the brain.

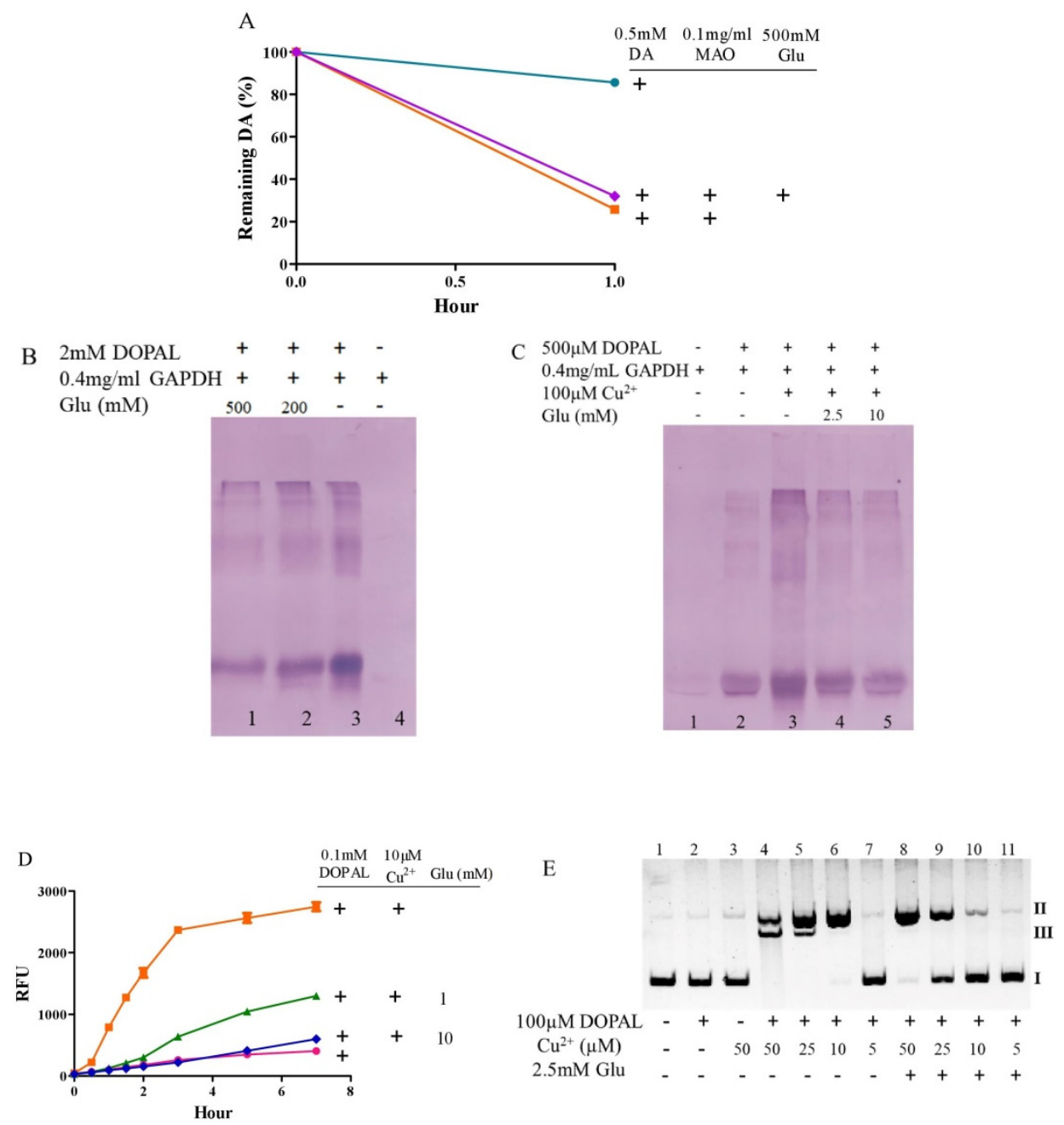

Figure 6. Glutamate attenuates side effects of DOPAL. (A) MAOmediated dopamine oxidation detected by HPLC. $(\mathbf{B}, \mathrm{C})$ DOPAL-caused quinoprotein in GAPDH, in the absence or presence of copper, respectively. (D) DOPAL-caused hydroxyl radical production detected by 3-CCA. (E) Copper/DOPAL induced DNA damage.Chemicals were mixed in 0.15 M PBS (pH 7.4) and incubated at $37^{\circ} \mathrm{C}$ for indicated time or $1 \mathrm{~h}$ for B, $20 \mathrm{~min}$ for $\mathrm{C}$ and $30 \mathrm{~min}$ for $\mathrm{E}$. Data are presented as mean \pm range $(n=2)$. Note: DA: Dopamine, Glu: Glutamate.

\section{Conclusions}

Glutamate and catecholamines are essential neurotransmitters that are endowed with corresponding important physiological functions. Catecholamines are susceptible to undergoing non-enzymatic and enzymatic oxidation, and copper is involved in both types of oxidation. Catecholamine oxidation, along with the formation of ROS, highly reactive quinones, and toxic DOPAL (in the case of dopamine), has been implicated as a causative pathological mechanism in several neurodegenerative diseases, including Parkinson's disease. For the first time, the present study demonstrates that the neurotransmitter glutamate, which is enriched and reaches a level 200-fold higher than that of dopamine (the major cate- 
cholamine) in terms of molar concentration in the brain, has a pronounced inhibitory effect on catecholamine oxidation in vitro when the molar ratio of glutamate/catecholamines is lower than 200, via the chelating and restraining redox activities of copper.

Author Contributions: Conceptualization, J.Z.; methodology, W.W.; software, X.W.; validation, J.Z., W.W., X.W. and C.S.Y.; formal analysis, W.W.; investigation, W.W. and X.W.; resources, J.Z.; data curation, W.W. and X.W.; writing—original draft preparation, W.W.; writing-review and editing, J.Z. and C.S.Y.; visualization, W.W. and X.W.; supervision, J.Z. and C.S.Y.; project administration, J.Z.; funding acquisition, J.Z. All authors have read and agreed to the published version of the manuscript.

Funding: This research was funded by the National Natural Science Foundation of China, grant numbers 31771971 and 31170648.

Institutional Review Board Statement: Not applicable.

Informed Consent Statement: Not applicable.

Data Availability Statement: The data presented in this study are available in the article. Additional data are available on request from the corresponding author.

Conflicts of Interest: The authors declare no conflict of interest.

\section{References}

1. Iuga, C.; Alvarez-Idaboy, J.R.; Vivier-Bunge, A. ROS initiated oxidation of dopamine under oxidative stress conditions in aqueous and lipidic environments. J. Phys. Chem. B 2011, 115, 12234-12246. [CrossRef]

2. Berke, J.D. What does dopamine mean? Nat. Neurosci. 2018, 21, 787-793. [CrossRef] [PubMed]

3. Iversen, S.D.; Iversen, L.L. Dopamine: 50 years in perspective. Trends Neurosci. 2007, 30, 188-193. [CrossRef] [PubMed]

4. Björklund, A.; Dunnett, S.B. Dopamine neuron systems in the brain: An update. Trends Neurosci. 2007, 30, 194-202. [CrossRef] [PubMed]

5. Pignatelli, M.; Bonci, A. Role of Dopamine Neurons in Reward and Aversion: A Synaptic Plasticity Perspective. Neuron 2015, 86, 1145-1157. [CrossRef] [PubMed]

6. Goldstein, D.S. Catecholamines 101. Clin. Auton. Res. 2010, 20, 331-352. [CrossRef]

7. Lai, C.T.; Yu, P.H. Dopamine- and L-beta-3,4-dihydroxyphenylalanine hydrochloride (L-Dopa)-induced cytotoxicity towards catecholaminergic neuroblastoma SH-SY5Y cells. Effects of oxidative stress and antioxidative factors. Biochem. Pharmacol. 1997, 53, 363-372. [CrossRef]

8. Kalyanaraman, B.; Felix, C.C.; Sealy, R.C. Semiquinone anion radicals of catechol(amine)s, catechol estrogens, and their metal ion complexes. Environ. Health Perspect. 1985, 64, 185-198. [CrossRef]

9. Miller, J.W.; Selhub, J.; Joseph, J.A. Oxidative damage caused by free radicals produced during catecholamine autoxidation: Protective effects of O-methylation and melatonin. Free Radic. Biol. Med. 1996, 21, 241-249. [CrossRef]

10. Jodko-Piórecka, K.; Litwinienko, G. Antioxidant activity of dopamine and L-DOPA in lipid micelles and their cooperation with an analogue of $\alpha$-tocopherol. Free Radic. Biol. Med. 2015, 83, 1-11. [CrossRef]

11. Monzani, E.; Nicolis, S.; Dell'Acqua, S.; Capucciati, A.; Bacchella, C.; Zucca, F.A.; Mosharov, E.V.; Sulzer, D.; Zecca, L.; Casella, L. Dopamine, Oxidative Stress and Protein-Quinone Modifications in Parkinson's and Other Neurodegenerative Diseases. Angew. Chem. Int. Ed. Engl. 2019, 58, 6512-6527. [CrossRef]

12. Hasegawa, T. Tyrosinase-expressing neuronal cell line as in vitro model of Parkinson's disease. Int. J. Mol. Sci. 2010, 11, 1082-1089. [CrossRef] [PubMed]

13. Fahn, S.; Cohen, G. The oxidant stress hypothesis in Parkinson's disease: Evidence supporting it. Ann. Neurol. 1992, 32, 804-812. [CrossRef]

14. Youdim, M.B.; Ben-Shachar, D.; Riederer, P. Is Parkinson's disease a progressive siderosis of substantia nigra resulting in iron and melanin induced neurodegeneration? Acta Neurol. Scand. Suppl. 1989, 126, 47-54. [CrossRef] [PubMed]

15. Luo, Y.; Roth, G.S. The roles of dopamine oxidative stress and dopamine receptor signaling in aging and age-related neurodegeneration. Antioxid. Redox Signal. 2000, 2, 449-460. [CrossRef] [PubMed]

16. Graham, D.G. Oxidative pathways for catecholamines in the genesis of neuromelanin and cytotoxic quinones. Mol. Pharmacol. 1978, 14, 633-643.

17. Segura-Aguilar, J.; Paris, I.; Muñoz, P.; Ferrari, E.; Zecca, L.; Zucca, F.A. Protective and toxic roles of dopamine in Parkinson's disease. J. Neurochem. 2014, 129, 898-915. [CrossRef]

18. Banerjee, K.; Munshi, S.; Sen, O.; Pramanik, V.; Roy Mukherjee, T.; Chakrabarti, S. Dopamine Cytotoxicity Involves Both Oxidative and Nonoxidative Pathways in SH-SY5Y Cells: Potential Role of Alpha-Synuclein Overexpression and Proteasomal Inhibition in the Etiopathogenesis of Parkinson's Disease. Parkinsons Dis. 2014, 2014, 878935. [CrossRef]

19. Dawson, T.M.; Dawson, V.L. Molecular pathways of neurodegeneration in Parkinson's disease. Science 2003, 302, 819-822. [CrossRef] 
20. Li, H.-T.; Lin, D.-H.; Luo, X.-Y.; Zhang, F.; Ji, L.-N.; Du, H.-N.; Song, G.-Q.; Hu, J.; Zhou, J.-W.; Hu, H.-Y. Inhibition of alphasynuclein fibrillization by dopamine analogs via reaction with the amino groups of alpha-synuclein. Implication for dopaminergic neurodegeneration. FEBS J. 2005, 272, 3661-3672. [CrossRef] [PubMed]

21. Rowe, D.B.; Le, W.; Smith, R.G.; Appel, S.H. Antibodies from patients with Parkinson's disease react with protein modified by dopamine oxidation. J. Neurosci. Res. 1998, 53, 551-558. [CrossRef]

22. Tisato, F.; Marzano, C.; Porchia, M.; Pellei, M.; Santini, C. Copper in diseases and treatments, and copper-based anticancer strategies. Med. Res. Rev. 2010, 30, 708-749. [CrossRef] [PubMed]

23. Asthana, A.; Bollapalli, M.; Tangirala, R.; Bakthisaran, R.; Mohan Rao, C. Hsp27 suppresses the Cu(2+)-induced amyloidogenicity, redox activity, and cytotoxicity of $\alpha$-synuclein by metal ion stripping. Free Radic. Biol. Med. 2014, 72, 176-190. [CrossRef]

24. Bindoli, A.; Rigobello, M.P.; Deeble, D.J. Biochemical and toxicological properties of the oxidation products of catecholamines. Free Radic. Biol. Med. 1992, 13, 391-405. [CrossRef]

25. Nishino, Y.; Ando, M.; Makino, R.; Ueda, K.; Okamoto, Y.; Kojima, N. Different mechanisms between copper and iron in catecholamines-mediated oxidative DNA damage and disruption of gene expression in vitro. Neurotox. Res. 2011, 20, 84-92. [CrossRef]

26. Spencer, W.A.; Jeyabalan, J.; Kichambre, S.; Gupta, R.C. Oxidatively generated DNA damage after Cu(II) catalysis of dopamine and related catecholamine neurotransmitters and neurotoxins: Role of reactive oxygen species. Free Radic. Biol. Med. 2011, 50, 139-147. [CrossRef]

27. Shao, B.; Mao, L.; Qu, N.; Wang, Y.-F.; Gao, H.-Y.; Li, F.; Qin, L.; Shao, J.; Huang, C.-H.; Xu, D.; et al. Mechanism of synergistic DNA damage induced by the hydroquinone metabolite of brominated phenolic environmental pollutants and $\mathrm{Cu}(\mathrm{II}): \mathrm{Formation}$ of DNA-Cu complex and site-specific production of hydroxyl radicals. Free Radic. Biol. Med. 2017, 104, 54-63. [CrossRef]

28. Hudspith, M.J. Glutamate: A role in normal brain function, anaesthesia, analgesia and CNS injury. Br. J. Anaesth. 1997, 78, 731-747. [CrossRef]

29. Crupi, R.; Impellizzeri, D.; Cuzzocrea, S. Role of Metabotropic Glutamate Receptors in Neurological Disorders. Front. Mol. Neurosci. 2019, 12, 20. [CrossRef]

30. McEntee, W.J.; Crook, T.H. Glutamate: Its role in learning, memory, and the aging brain. Psychopharmacology 1993, $111,391-401$. [CrossRef]

31. Djuricić, B. Glutamate in brain: Transmitter and poison. Glas. Srp. Akad. Nauka. Med. 2002, 47, 55-76.

32. Simonyi, A.; Schachtman, T.R.; Christoffersen, G.R.J. The role of metabotropic glutamate receptor 5 in learning and memory processes. Drug News Perspect. 2005, 18, 353-361. [CrossRef]

33. Egbenya, D.L.; Hussain, S.; Lai, Y.-C.; Xia, J.; Anderson, A.E.; Davanger, S. Changes in synaptic AMPA receptor concentration and composition in chronic temporal lobe epilepsy. Mol. Cell. Neurosci. 2018, 92, 93-103. [CrossRef]

34. Wang, R.; Reddy, P.H. Role of Glutamate and NMDA Receptors in Alzheimer's Disease. J. Alzheimers Dis. JAD 2017, 57, 1041-1048. [CrossRef]

35. Plaitakis, A.; Shashidharan, P. Glutamate transport and metabolism in dopaminergic neurons of substantia nigra: Implications for the pathogenesis of Parkinson's disease. J. Neurol. 2000, 247 (Suppl. 2), II25-II35. [CrossRef]

36. Featherstone, D.E.; Shippy, S.A. Regulation of synaptic transmission by ambient extracellular glutamate. Neuroscientist 2008, 14, 171-181. [CrossRef]

37. Takahashi, N.; Miner, L.L.; Sora, I.; Ujike, H.; Revay, R.S.; Kostic, V.; Jackson-Lewis, V.; Przedborski, S.; Uhl, G.R. VMAT2 knockout mice: Heterozygotes display reduced amphetamine-conditioned reward, enhanced amphetamine locomotion, and enhanced MPTP toxicity. Proc. Natl. Acad. Sci. USA 1997, 94, 9938-9943. [CrossRef] [PubMed]

38. Yuan, J.; Callahan, B.T.; McCann, U.D.; Ricaurte, G.A. Evidence against an essential role of endogenous brain dopamine in methamphetamine-induced dopaminergic neurotoxicity. J. Neurochem. 2001, 77, 1338-1347. [CrossRef]

39. Ponzio, F.; Achilli, G.; Calderini, G.; Ferretti, P.; Perego, C.; Toffano, G.; Algeri, S. Depletion and recovery of neuronal monoamine storage in rats of different ages treated with reserpine. Neurobiol. Aging 1984, 5, 101-104. [CrossRef]

40. Yu, G.; Liu, H.; Zhou, W.; Zhu, X.; Yu, C.; Wang, N.; Zhang, Y.; Ma, J.; Zhao, Y.; Xu, Y.; et al. In vivo protein targets for increased quinoprotein adduct formation in aged substantia nigra. Exp. Neurol. 2015, 271, 13-24. [CrossRef] [PubMed]

41. Miyazaki, I.; Asanuma, M.; Diaz-Corrales, F.J.; Fukuda, M.; Kitaichi, K.; Miyoshi, K.; Ogawa, N. Methamphetamine-induced dopaminergic neurotoxicity is regulated by quinone-formation-related molecules. FASEB J. 2006, 20, 571-573. [CrossRef]

42. Umek, N.; Geršak, B.; Vintar, N.; Šoštarič, M.; Mavri, J. Dopamine Autoxidation Is Controlled by Acidic pH. Front. Mol. Neurosci. 2018, 11, 467. [CrossRef] [PubMed]

43. Zecca, L.; Zucca, F.A.; Wilms, H.; Sulzer, D. Neuromelanin of the substantia nigra: A neuronal black hole with protective and toxic characteristics. Trends Neurosci. 2003, 26, 578-580. [CrossRef] [PubMed]

44. Hastings, T.G.; Lewis, D.A.; Zigmond, M.J. Role of oxidation in the neurotoxic effects of intrastriatal dopamine injections Proc. Natl. Acad. Sci. USA 1996, 93, 1956-1961. [CrossRef]

45. Hastings, T.G.; Zigmond, M.J. Identification of catechol-protein conjugates in neostriatal slices incubated with $\left[{ }^{3} \mathrm{H}\right] \mathrm{dopamine:}$ Impact of ascorbic acid and glutathione. J. Neurochem. 1994, 63, 1126-1132. [CrossRef] [PubMed]

46. Wang, N.; Wang, Y.; Yu, G.; Yuan, C.; Ma, J. Quinoprotein adducts accumulate in the substantia nigra of aged rats and correlate with dopamine-induced toxicity in SH-SY5Y cells. Neurochem. Res. 2011, 36, 2169-2175. [CrossRef] 
47. Miller, D.M.; Buettner, G.R.; Aust, S.D. Transition metals as catalysts of “autoxidation" reactions. Free Radic. Biol. Med. 1990, 8, 95-108. [CrossRef]

48. Pham, A.N.; Waite, T.D. Cu(II)-catalyzed oxidation of dopamine in aqueous solutions: Mechanism and kinetics. J. Inorg. Biochem. 2014, 137, 74-84. [CrossRef]

49. Ryan, T.P.; Miller, D.M.; Aust, S.D. The role of metals in the enzymatic and nonenzymatic oxidation of epinephrine. J. Biochem. Toxicol. 1993, 8, 33-39. [CrossRef] [PubMed]

50. Sang, S.; Lee, M.-J.; Hou, Z.; Ho, C.-T.; Yang, C.S. Stability of tea polyphenol (-)-epigallocatechin-3-gallate and formation of dimers and epimers under common experimental conditions. J. Agric. Food Chem. 2005, 53, 9478-9484. [CrossRef]

51. Rico-Yuson, C.A.; Hornyak, G.L.; Bora, T. Cyanide-free environment-friendly alternative to copper electroplating for zinc die-cast alloys. Environ. Sci. Pollut. Res. Int. 2021, 28, 38065-38073. [CrossRef]

52. Niu, J.; Guo, D.; Zhang, W.; Tang, J.; Tang, G.; Yang, J.; Wang, W.; Huo, H.; Jiang, N.; Cao, Y. Preparation and characterization of nanosilica copper (II) complexes of amino acids. J. Hazard. Mater. 2018, 358, 207-215. [CrossRef]

53. Bisaglia, M.; Bubacco, L. Copper Ions and Parkinson's Disease: Why Is Homeostasis So Relevant? Biomolecules 2020, 10, 195. [CrossRef]

54. Stöckel, J.; Safar, J.; Wallace, A.C.; Cohen, F.E.; Prusiner, S.B. Prion protein selectively binds copper (II) ions. Biochemistry 1998, 37, 7185-7193. [CrossRef] [PubMed]

55. Pall, H.S.; Williams, A.C.; Blake, D.R.; Lunec, J.; Gutteridge, J.M.; Hall, M.; Taylor, A. Raised cerebrospinal-fluid copper concentration in Parkinson's disease. Lancet 1987, 2, 238-241. [CrossRef]

56. Boll, M.-C.; Alcaraz-Zubeldia, M.; Montes, S.; Rios, C. Free copper, ferroxidase and SOD1 activities, lipid peroxidation and NO(x) content in the CSF. A different marker profile in four neurodegenerative diseases. Neurochem. Res. 2008, 33, 1717-1723. [CrossRef] [PubMed]

57. Pattison, D.I.; Dean, R.T.; Davies, M.J. Oxidation of DNA, proteins and lipids by DOPA, protein-bound DOPA, and related catechol(amine)s. Toxicology 2002, 177, 23-37. [CrossRef]

58. Lévay, G.; Ye, Q.; Bodell, W.J. Formation of DNA adducts and oxidative base damage by copper mediated oxidation of dopamine and 6-hydroxydopamine. Exp. Neurol. 1997, 146, 570-574. [CrossRef] [PubMed]

59. Dawson, J.H.; Dooley, D.M.; Gray, H.B. Coordination environment and fluoride binding of type 2 copper in the blue copper oxidase ceruloplasmin. Proc. Natl. Acad. Sci. USA 1978, 75, 4078-4081. [CrossRef]

60. Patel, B.N.; David, S. A novel glycosylphosphatidylinositol-anchored form of ceruloplasmin is expressed by mammalian astrocytes. J. Biol. Chem. 1997, 272, 20185-20190. [CrossRef]

61. Patel, B.N.; Dunn, R.J.; Jeong, S.Y.; Zhu, Q.; Julien, J.-P.; David, S. Ceruloplasmin regulates iron levels in the CNS and prevents free radical injury. J. Neurosci. 2002, 22, 6578-6586. [CrossRef]

62. Gutteridge, J.M. Inhibition of the Fenton reaction by the protein caeruloplasmin and other copper complexes. Assessment of ferroxidase and radical scavenging activities. Chem.-Biol. Interact. 1985, 56, 113-120. [CrossRef]

63. De Domenico, I.; Ward, D.M.; di Patti, M.C.B.; Jeong, S.Y.; David, S.; Musci, G.; Kaplan, J. Ferroxidase activity is required for the stability of cell surface ferroportin in cells expressing GPI-ceruloplasmin. EMBO J. 2007, 26, 2823-2831. [CrossRef] [PubMed]

64. Sato, M.; Gitlin, J.D. Mechanisms of copper incorporation during the biosynthesis of human ceruloplasmin. J. Biol. Chem. 1991, 266, 5128-5134. [CrossRef]

65. Nittis, T.; Gitlin, J.D. The copper-iron connection: Hereditary aceruloplasminemia. Semin. Hematol. 2002, 39, 282-289. [CrossRef]

66. Løvstad, R.A. Activating effect of copper ions on the interaction of ceruloplasmin with catecholamines. Gen. Pharmacol. 1979, 10, 147-151. [CrossRef]

67. Rosei, M.A.; Foppoli, C.; Wang, X.T.; Coccia, R.; Mateescu, M.A. Production of melanins by ceruloplasmin. Pigment Cell Res. 1998, 11, 98-102. [CrossRef]

68. Vashchenko, G.; MacGillivray, R.T.A. Multi-copper oxidases and human iron metabolism. Nutrients 2013, 5, 2289-2313. [CrossRef]

69. Curzon, G. The effects of some ions and chelating agents on the oxidase activity of caeruloplasmin. Biochem. J. 1960, 77, 66-73. [CrossRef]

70. Bharucha, K.J.; Friedman, J.K.; Vincent, A.S.; Ross, E.D. Lower serum ceruloplasmin levels correlate with younger age of onset in Parkinson's disease. J. Neurol. 2008, 255, 1957-1962. [CrossRef]

71. Jin, L.; Wang, J.; Zhao, L.; Jin, H.; Fei, G.; Zhang, Y.; Zeng, M.; Zhong, C. Decreased serum ceruloplasmin levels characteristically aggravate nigral iron deposition in Parkinson's disease. Brain. 2011, 134, 50-58. [CrossRef] [PubMed]

72. Jin, L.; Wang, J.; Jin, H.; Fei, G.; Zhang, Y.; Chen, W.; Zhao, L.; Zhao, N.; Sun, X.; Zeng, M.; et al. Nigral iron deposition occurs across motor phenotypes of Parkinson's disease. Eur. J. Neurol. 2012, 19, 969-976. [CrossRef]

73. Olivieri, S.; Conti, A.; Iannaccone, S.; Cannistraci, C.V.; Campanella, A.; Barbariga, M.; Codazzi, F.; Pelizzoni, I.; Magnani, G.; Pesca, M.; et al. Ceruloplasmin oxidation, a feature of Parkinson's disease CSF, inhibits ferroxidase activity and promotes cellular iron retention. J. Neurosci. 2011, 31, 18568-18577. [CrossRef]

74. Ayton, S.; Lei, P.; Duce, J.A.; Wong, B.X.W.; Sedjahtera, A.; Adlard, P.A.; Bush, A.I.; Finkelstein, D.I. Ceruloplasmin dysfunction and therapeutic potential for Parkinson disease. Ann. Neurol. 2013, 73, 554-559. [CrossRef]

75. Barbariga, M.; Curnis, F.; Andolfo, A.; Zanardi, A.; Lazzaro, M.; Conti, A.; Magnani, G.; Volontè, M.A.; Ferrari, L.; Comi, G.; et al. Ceruloplasmin functional changes in Parkinson's disease-cerebrospinal fluid. Mol. Neurodegener. 2015, 10, 59. [CrossRef] [PubMed] 
76. Agarwal, K.; Sharma, A.; Talukder, G. Effects of copper on mammalian cell components. Chem.-Biol. Interact. 1989, 69, 1-16. [CrossRef]

77. Hasebe, Y.; Toda, S.; Aoki, K.; Tonobe, H.; Uchiyama, S. Specific and amplified current responses to histidine and histamine using immobilized copper-monoamine oxidase membrane electrode, based on novel ascorbate oxidase activity induced by exogenous ligands. Anal. Biochem. 1997, 251, 32-38. [CrossRef] [PubMed]

78. Goldstein, D.S.; Jinsmaa, Y.; Sullivan, P.; Sharabi, Y. N-Acetylcysteine Prevents the Increase in Spontaneous Oxidation of Dopamine During Monoamine Oxidase Inhibition in PC12 Cells. Neurochem. Res. 2017, 42, 3289-3295. [CrossRef] [PubMed]

79. Follmer, C.; Coelho-Cerqueira, E.; Yatabe-Franco, D.Y.; Araujo, G.D.T.; Pinheiro, A.S.; Domont, G.B.; Eliezer, D. Oligomerization and Membrane-binding Properties of Covalent Adducts Formed by the Interaction of $\alpha$-Synuclein with the Toxic Dopamine Metabolite 3,4-Dihydroxyphenylacetaldehyde (DOPAL). J. Biol. Chem. 2015, 290, 27660-27679. [CrossRef]

80. Burke, W.J. 3,4-dihydroxyphenylacetaldehyde: A potential target for neuroprotective therapy in Parkinson's disease. Curr. Drug Targets CNS Neurol. Disord. 2003, 2, 143-148. [CrossRef]

81. Jinsmaa, Y.; Isonaka, R.; Sharabi, Y.; Goldstein, D.S. 3,4-Dihydroxyphenylacetaldehyde Is More Efficient than Dopamine in Oligomerizing and Quinonizing -Synuclein. J. Pharmacol. Exp. Ther. 2020, 372, 157-165. [CrossRef] [PubMed] 